IZA DP No. 9547

Social Assistance in Five Countries in North-Western Europe

Hans Hansen

Marie Louise Schultz-Nielsen

December 2015 


\title{
Social Assistance in Five Countries in North-Western Europe
}

\author{
Hans Hansen \\ Rockwool Foundation Research Unit \\ Marie Louise Schultz-Nielsen \\ Rockwool Foundation Research Unit \\ and IZA
}

Discussion Paper No. 9547

December 2015

\author{
IZA \\ P.O. Box 7240 \\ 53072 Bonn \\ Germany \\ Phone: +49-228-3894-0 \\ Fax: +49-228-3894-180 \\ E-mail: iza@iza.org
}

\begin{abstract}
Any opinions expressed here are those of the author(s) and not those of IZA. Research published in this series may include views on policy, but the institute itself takes no institutional policy positions. The IZA research network is committed to the IZA Guiding Principles of Research Integrity.

The Institute for the Study of Labor (IZA) in Bonn is a local and virtual international research center and a place of communication between science, politics and business. IZA is an independent nonprofit organization supported by Deutsche Post Foundation. The center is associated with the University of Bonn and offers a stimulating research environment through its international network, workshops and conferences, data service, project support, research visits and doctoral program. IZA engages in (i) original and internationally competitive research in all fields of labor economics, (ii) development of policy concepts, and (iii) dissemination of research results and concepts to the interested public.
\end{abstract}

IZA Discussion Papers often represent preliminary work and are circulated to encourage discussion. Citation of such a paper should account for its provisional character. A revised version may be available directly from the author. 


\section{ABSTRACT}

\section{Social Assistance in Five Countries in North-Western Europe*}

In this paper, we calculate the disposable incomes in 2012 of three selected family types receiving social assistance in five countries in north-western Europe. We also calculate the net replacement rates for families receiving social assistance, calculated on the basis of the disposable incomes of 'average workers' in the five countries, as reported by the OECD. The results show that the Danish social assistance benefits are the highest, or among the highest, of the five countries; Swedish benefits are the lowest or among the lowest, but very much in line with those in Germany. The benefits in the United Kingdom for families with children are in the middle of the group, whereas the UK's benefits for single persons without children are among the lowest. In the Netherlands the picture is more mixed; for single persons without children the benefits are among the highest, for lone parents they are around the middle, and for couples with children the benefits are comparatively low.

JEL Classification: J38, J65, I38

Keywords: unemployment, net replacement rate, social assistance benefits

Corresponding author:

Marie Louise Schultz-Nielsen

The Rockwool Foundation Research Unit

Sølvgade 10

1307 Copenhagen $\mathrm{K}$

Denmark

E-mail: mls@rff.dk

\footnotetext{
* We wish to express our thanks to Bodil Nielsen for her help with the preparation of this study paper. We also thank Bjørn Gustafson, Torben M. Andersen, Jan Rose Skaksen and Torben Tranæs for their comments on a previous version of the text. Naturally, however, the views expressed are the sole responsibility of the authors.
} 


\section{Introduction}

In this paper we compare social assistance benefits in Denmark, Sweden, the United Kingdom $^{1}$, Germany and the Netherlands. These countries have been selected as representing social-democratic, liberal and conservative welfare models (see Esping-Andersen, 1990). The paper is based on Chapter 11 of Hansen and Schultz-Nielsen (2015).

The comparisons are made on the basis of the rules for social assistance in the various countries as they were in 2012. The systems in Sweden, Germany and the Netherlands have remained largely unaltered since then, while there have been certain changes in Denmark and the $\mathrm{UK}^{2}$.

The comparisons are illustrated with a number of empirical examples in which three family types - a single person, a lone parent with two children and a couple with two children - were in receipt of social assistance benefits in 2012 in their various countries. The benefits are subdivided into their main components. The relationships between social assistance and unemployment benefit in the various countries are also briefly discussed.

In all the countries compared except Denmark, the benefits under the social assistance schemes are paid free of tax. In the case of the Denmark, the benefits reported here are calculated after the deduction of tax, so that the final figures are comparable with those for the other countries. Another important difference is that Sweden, the UK and Germany place greater weight on covering the housing costs of social assistance recipients than do Denmark and the Netherlands. In the first three countries these costs are covered separately and usually in full, whereas the costs are only partially covered in Denmark and the Netherlands.

It is notoriously difficult to make international comparisons that take housing costs into account, because housing conditions and housing costs are so very different in different countries. Nevertheless, we do attempt to make comparisons for the various family types in our five countries for the year 2012. This we do by comparing both the net replacement rates for recipients of social assistance and their net disposable incomes recalculated in common PPP (Purchasing Power Parity)-corrected values. The calculation of the levels of net replacement rates draws on the OECD's methods, and the incomes of families in work used in calculating net replacement rates are directly based on the AW (Average Worker) descriptions and calculations in Taxing Wages 2011-2012 (OECD, 2013).

\footnotetext{
1 The rules applied for the UK are those for Great Britain, whether they in all detail also apply for Northern Ireland has not been investigated.

2 In the UK, the Welfare Reform Act of 2012 introduced a number of changes with effect from 2013. A benefit cap now limits the total amount of assistance that a family can receive, though this cap has been set fairly high. The 'under-occupancy penalty' (often referred to colloquially as 'the Bedroom Tax') reduces the amount of Housing Benefit paid to recipients who are deemed to have more rooms in their homes than they need in relation to the size of their families. Finally, a new all-in-one benefit called Universal Credit was launched in 2013, but it is being introduced only gradually. In Denmark, a social assistance reform was passed in 2014, the main change introduced being a reduction in the amount of benefit payable to recipients aged 25-29. In 2015 a benefit cap was brought in for recipients of social assistance, limiting the total amount of benefit they can receive. In addition, an 'integration benefit' was introduced in 2015 which cuts the amount of benefit payable to refugees and other immigrants from countries outside the EU who have not been resident in Denmark for seven out of the previous eight years.
} 
The three family types included in the study, as noted above, are a single person, a single person with two children of school age, and a couple (married or cohabiting) with two school-age children. The adults in the families are aged over 25 , which means that they receive the standard social assistance benefit and are entitled to full personal deductions in their tax calculations. The children are aged 7-10, and in consequence the families are entitled to child benefit for this age group under the rules regarding child benefit in their respective countries.

The calculations of net replacement rates are based on two possible situations for each family type: either the adults are in employment and thus receive wage income, or they are unemployed and receive social assistance. In the case of couples, the situations considered are those where either both adults are working, or both are unemployed. The situation where one adult is employed and the other unemployed is not included in the comparisons.

The calculations of the disposable incomes of people in work are based on the wages for the OECD's Average Worker (AW) for each country, as published in Taxing Wages. Single persons, lone parents and the higher-paid members of couples are counted as receiving 100 percent of the relevant AW income, while the lower-paid members of each couple are counted as receiving $80 \%$ of this wage.

The figure for rent for housing in Denmark used in the calculations is that given for the relevant family types in Fordeling og incitamenter 2004 (Income distribution and incentives 2004), published by the Ministry of Finance (see Finansministeriet, 2004). These rents are adjusted in accordance with changes in housing rents as given by the Danish consumer prices index (see Danmarks Statistik, 2015). No account is taken of costs for heating, water and electricity. To evaluate the support provided towards housing costs in the other countries we use housing rents that are equivalent to those in Denmark, in that it is assumed that rents make up the same proportions of 100 percent AW income ${ }^{3}$ as they do in Denmark, namely 12.1 percent for single persons and 15.9 percent both for lone parents with two children and for couples with two children. This does not mean that rents in the other four countries are assumed to be exactly the same as in Denmark for the various family types, but rather that housing costs are calculated as making up the same proportions of AW wages in all the countries considered.

\section{Denmark}

The Danish social assistance (kontanthjælp) system is described in detail in Hansen and Schultz-Nielsen (2015) which also includes a summary in english. An outline of the main points will suffice here. In order to obtain social assistance in Denmark it is not sufficient to have a low income, it is not a 'topping-up' scheme. A social event (job loss, divorce etc.) must have occurred and the ability to provide for one self or the family is no longer there. Fulfilling these criteria the principal element in the social assistance scheme is a basic payment (grundsats); the amount of the grundsats depended in 2012 on whether the recipient was aged over or under 25 and whether he or she had dependent children. The grundsats payment is taxable. Assistance with one-off expenses may be provided within the framework of the social assistance scheme. In some cases, it is possible to receive a housing supplement (boligtillæg). In

\footnotetext{
3 AW income in Denmark in 2012 was DKK 392,456 (approximately EUR 52,600).
} 
addition, people living in rental accommodation in particular may receive housing benefit (boligstøtte), which covers part of the rent, and families with children can receive child benefits (børneydelser). None of these additional benefits - assistance with specific costs, housing benefit or child benefit - are liable to tax. With the exception of assistance for specific, primarily one-off expenses, all these elements are included in the comparisons in this paper.

As mentioned above, the calculations below cover three family types: single persons, lone parents with two children and couples with two children. It is assumed that all receipts of social assistance payments and wage income start from the first day of the year in question and continue throughout the year. Similarly, it is assumed that the levels of housing rent used are 'approved', i.e. that they are not judged by the authorities to be unreasonably high.

Table 1 shows calculations of the disposable income both before and after housing costs for recipients of social assistance in Denmark in all three family types in 2012.

Table 1. Disposable income before and after housing costs for selected family types in Denmark, 2012

\begin{tabular}{rcc} 
Single person & $\begin{array}{c}\text { Lone parent, } \\
\text { 2 children } \\
\text { (aged 7-10) }\end{array}$ & $\begin{array}{c}\text { Couple, } \\
\text { 2 children } \\
\text { (aged 7-10) }\end{array}$ \\
\hline------------ \\
124,020 & 164,784 & 329,568 \\
93,391 & 118,935 & 237,870 \\
& & \\
93,391 & 66,144 & 21,264 \\
47,394 & 185,079 & 259,134 \\
7,109 & 62,352 & 62,352 \\
7,885 & 37,411 & 8,649 \\
32,400 & 0 & 0 \\
60,991 & 24,941 & 53,703 \\
\hline & 160,138 & 205,431 \\
\hline
\end{tabular}

Benefits per year:

Personal benefits for adults

As above, after deduction of

social costs

Child benefit

Total benefits per year

Rent

7,394

Housing benefit

7,885

Housing supplement

32,400

Net rent

Disposable income after

housing costs

Source: Own calculations, based on Jappe $(2012,2013)$. No account is taken of costs of water, heating and electricity, which may be covered by the housing supplement.

The figures in Table 1 are given in Danish kroner (DKK) and in 2012 values. Before housing costs, disposable income was DKK 93,391 for a single person, DKK 185,079 for a lone parent with two children and DKK 259,134 for a couple with two children. In 2012 the rules for receipt of social assistance were the same for married couples and for cohabiting couples in cases where both members of the couple received social assistance, and they can therefore be considered together here. When both members of a couple receive the same income, then there is no question of unused personal tax deductions to be taken into account, and thus the members of both married couples and cohabiting couples pay the same amount of tax on the income sources used in these calculations. ${ }^{4}$

\footnotetext{
${ }^{4}$ Unused tax deductions can otherwise be transferred from one member of a married couple to the other, this is not the case for cohabiting couples.
} 
Table 1 shows the rents for housing (in DKK/year) for the three Danish family types. As indicated previously, these rents provide the basis for calculating the rents assumed for the other four countries. The rents for each country thus calculated are then used in the calculation of the disposable incomes of working families after housing costs, and thus in the calculation later in this paper of net replacement rates. Disposable incomes after housing costs are also shown in the table, and are calculated as being DKK 60,991 for single persons, DKK 160,138 for lone parents with two children and DKK 205,431 for couples with two children.

\section{Relationship of social assistance to unemployment insurance in Denmark}

In Denmark, membership of unemployment insurance funds is voluntary. Social assistance is thus an optional alternative to unemployment benefit. Denmark is the only country among the five studied in this paper where this is the case.

\section{Sweden}

The Swedish social assistance system is called försörjningsstöd. It consists of two elements: a riksnorm (national standard) and coverage of reasonable expenses, especially those for housing. In addition, within the framework of the ekonomiskt bistånd (financial support) system, which includes försörjningsstöd, there are possibilities for one-off costs to be covered, e.g. costs of medicine and dentist's fees. It is not necessary to demonstrate the occurrence of a change in circumstances (a social event) to become entitled to försörjningsstöd; it is enough to have insufficient income. The system is of the 'topping up' type, whereby existing income is supplemented by benefits up to the level of försörjningsstöd.

The riksnorm is fixed annually by the Swedish parliament on the basis of family budget studies and price inflation. This level is only for the guidance of municipalities, who may give more or less support than the national amount, depending on the circumstances of the recipient families.

As noted above, the riksnorm is based on budget surveys. These take account of family size. Each family member is allocated a certain amount for food, clothes and footwear, leisure, hygiene and other individual everyday expenses. In families with couples, however, a joint amount is allocated to the pair. This takes 'economies of scale' into account, so that a couple receives less than double the amount of two individuals. Children and young people are allocated an amount that increases with their age. Finally, the riksnorm includes an amount for joint family expenses such as newspapers, telephone and TV licence. This amount varies according to the size of the family but again takes 'economies of scale' into account.

The riksnorm amounts for the family types considered here - single persons, lone parents with two children and couples with two children, with no distinction made between married couples and cohabiting couples - were, as of 1 January 2012, as shown in Table 2 (in Swedish kronor, SEK).

Several types of income are deducted from the benefits. This applies, for example, to different types of payments for children - both barnbidrag (child benefit) and underhållsbidrag (child support payments from another parent), and both for lone parents and for couples with chil- 
dren. This contrasts with systems like the Danish, where these payments do not affect social assistance, and where there is no calculation of separate individualised payments for children. In both Denmark and Sweden, payments in respect of children are particularly important for lone parents, making up 26 percent and 20 percent in the two countries respectively of the disposable income after housing costs of lone parents in work who earn 100 percent of the AW wage. In Table 2, payments with respect to children are offset against total benefits, though this has no effect on the total amount that families receive.

Table 2. Disposable income before and after housing costs for selected family types in Sweden, 2012

\begin{tabular}{|c|c|c|c|}
\hline & Single person & $\begin{array}{l}\text { Lone parent, } \\
2 \text { children } \\
\text { (aged } 7-10 \text { ) }\end{array}$ & $\begin{array}{c}\text { Couple, } \\
2 \text { children } \\
\text { (aged } 7-10 \text { ) }\end{array}$ \\
\hline Amount of benefit: & ------------. & SEK --. & - n \\
\hline Adults & 35,040 & 35,040 & 63,240 \\
\hline Children & - & 57,360 & 57,360 \\
\hline Joint & 11,040 & 15,600 & 17,760 \\
\hline Benefit in total & 46,080 & 108,000 & 138,360 \\
\hline $\begin{array}{l}\text { Amount of child benefit off- } \\
\text { set }\end{array}$ & 0 & 57,552 & 27,000 \\
\hline $\begin{array}{l}\text { Amount of benefit remain- } \\
\text { ing }\end{array}$ & 46,080 & 50,448 & 111,360 \\
\hline Total benefits per year & 46,080 & 108,000 & 138,360 \\
\hline Rent & 46,863 & 61,580 & 61,580 \\
\hline Total grant towards rent & 46,863 & 61,580 & 61,580 \\
\hline Net rent & 0 & 0 & 0 \\
\hline $\begin{array}{l}\text { Disposable income after } \\
\text { housing costs }\end{array}$ & 46,080 & 108,000 & 138,360 \\
\hline
\end{tabular}

Amount of benefit:

Adults

Children

Joint

Benefit in total

Amount of child benefit off-

set

Sources: www.socialstyrelsen.se and own assumptions regarding levels of rent.

Försörjningsstöd includes, as already mentioned, payments for 'reasonable' household expenses, including electricity bills and home insurance. Such reasonable household expenses (skäliga boendekostnader) vary according to where in the country the benefit recipients live. The amounts are highest in Stockholm, somewhat lower in other large towns, and lowest in rural areas. In Gothenburg, Sweden's second largest city, the maximum amounts for skäliga boendekostnader were as shown below in 2012:

$\begin{array}{lll}\text { Family size } & \begin{array}{l}\text { Maximum reasonable annual } \\ \text { household expenses }\end{array} & \begin{array}{l}\text { Average ann } \\ \text { expenses }\end{array} \\ 1-2 \text { adults } & \text { SEK 84,900 } & \text { SEK 61,500 } \\ 1-2 \text { adults }+2 \text { children } & \text { SEK 131,700 } & \text { SEK 92,700 }\end{array}$

Source: Göteborgs Stad Stadsledningskontor (2012). 
We have no information about the distribution of payments around the average, but it would seem that there is plenty of room below the ceiling for 'reasonable household expenses'.

Expenses for travel to work and membership of trades unions and unemployment insurance funds can also be covered. It seems, then, that household expenses can be fully covered within the limits of what is considered 'reasonable'. If a family receives housing benefit (bostadsbid$\mathrm{rag}$ ), this is offset against the overall benefit paid.

In order to elucidate the coverage of housing expenses by benefits, we use rents that are equivalent to those in Denmark on the assumption that rents for housing in Sweden represent the same proportion of the Swedish AW income as Danish rents make up of the Danish AW income. Table 2 includes the rent figures for Sweden in SEK/year. The table also gives the disposable income remaining after deduction of rent from total annual benefit, with net rent costs in this case being zero. Thus, disposable annual income for benefit recipients in Sweden is the same both before and after housing costs, i.e. SEK 46,080 for single persons, SEK 108,000 for lone parents with two children and SEK 138,360 for couples with two children. The rents for housing shown are well under the ceiling for 'reasonable' household costs in Gothenburg in 2012, but obviously this may not be the case everywhere in Sweden. It should be noted that no account has been taken of the costs of electricity, water and heating in the calculations of housing costs in the five countries, even though these costs are covered under benefit schemes in some of the countries (for example, in the Danish housing supplement, or in the coverage of the cost of electricity as part of household costs under the Swedish försörjningsstöd.

\section{Relationship of social assistance to unemployment insurance in Sweden}

In Sweden there is a basic unemployment insurance that pays out a basic amount to everyone who fulfils the relevant work criterion, i.e. who has been in employment for a certain amount of time before becoming unemployed. In addition there is a voluntary system of insurance for those who, as well as the employment requirement, also fulfil the criteria for membership of an unemployment insurance fund. Under the voluntary insurance system, payments depend on previous income, up to a certain maximum level. In Sweden, then, an unemployed person will receive försörjningsstöd if he or she does not fulfil the work requirements for basic unemployment insurance, or if the period of payment of unemployment insurance has come to an end. It is not possible to choose försörjningsstöd as an optional alternative to unemployment benefit.

\section{The United Kingdom}

There are two types of social assistance in the United Kingdom. The first is Jobseeker's Allowance (JSA). There are two types of JSA: Income-based Jobseeker's Allowance (JSA (IB)) and Contribution-based Jobseeker's Allowance (JSA (C)). JSA (IB) is payable in the case of unemployment, either when conditions are not fulfilled for payment of Contribution-based Jobseeker's Allowance (JSA (C)), or when the six-month period of eligibility for JSA (C) has come to an end. JSA (IB) thus functions in the same way as the Swedish försörjningsstöd in relation to payments from unemployment insurance. 
The second benefit available is Income Support (IS), which is payable to people who have low or no income for reasons other than unemployment. JSA (IB) and IS have the same structure and the amounts of benefit are identical, so that for our purposes there is no need to distinguish between them. Both schemes are of the 'topping up' type; having a low income, possibly as a result of working only part-time (16 hours per week or less), is sufficient ground to be entitled to receive benefit.

The rates for JSA (IB)/IS benefits vary according to the age of the recipients; young people under the age of 25 receive benefits at a lower rate. There is only one rate per family type. However, there is a single 'Premium' payment, an extra sum granted to families with children among our family types. As in Sweden, these payments reflect the economies of scale assumed in larger families, so that a couple, for example, receives less than twice the amount for a lone parent. However, this weighting disappears partially or completely in cases where both the Premium and child benefit are payable, as the upper section of Table 3 shows.

Previously, JSA (IB)/IS included basic payments for children. These have now been replaced by payments under the Child Tax Credit (CTC) system, which is a generally applicable scheme in the UK. Families with children also receive Child Benefit, again under a general scheme for everyone. The annual benefits received by our family types in 2012 are shown in Table 3 below in GBP.

Table 3. Disposable income before and after housing costs for selected family types in the UK, 2012

\section{Single person}

Amount of benefit:

Personal benefits for adults

Premium

Child benefit

CTC

Total benefits per year

Rent

Total grant towards rent

Net rent

Disposable income after

housing costs

\section{Lone parent,}

2 children

(aged 7-10)

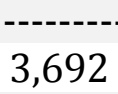

3,692 GBP

3,692

905

1,752

5,925

12,274

3,692

4,342

5,705

5,705

4,342

3,692

$0 \quad 0$

12,274
Couple, 2 children (aged 7-10)

Sources: www.gov.uk and own assumptions regarding levels of rent.

Other income is offset against personal benefits and the Premium. CTC benefits are tapered against income above certain income levels. This tapering, however, is not relevant for recipients of JSA (IB)/IS. Child Benefit consists of a fixed amount irrespective of income.

The family types covered by this overview are also entitled to Housing Benefit. With JSA (IB)/IS income, and if one lives in council or social housing, the rent will be covered in full, though possibly with certain reductions down to the 'eligible rent'. For tenants in private rental accommodation, there are limits on how high a rent can be supported. The ceiling var- 
ies according to where in the country the recipient lives, just like the Swedish skälige boendekostnader; the limit is highest in London and lowest in rural areas. The country is divided up into 'broader rental market areas' (BRMAs), and a ceiling is set for each. For the Borough of Northampton, in the English Midlands, the ceilings in 2012 for the relevant housing sizes for our family types were GBP 5,100 for one-bedroom accommodation and GBP 6,300 for twobedroom accommodation. With the income sources indicated above, families would have their rent covered in full. For families living in private accommodation the benefit is called Local Housing Allowance (LHA), and it corresponds to Housing Benefit for expenses up to the relevant ceiling.

Here again we use amounts for rents that correspond to those in Denmark, insofar as they are calculated on the assumption that rent accounts for the same proportion of the UK AW's income as Danish rents make up of the Danish AW's income. Annual benefits in the UK in GBP are presented in Table 3, and amount to GBP 3,692 for a single person, GBP 12,274 for a lone parent with two children and GBP 14,377 for a couple with two children. Since all the calculated rents in this case are covered by Housing Benefit - they are below the ceiling for Northampton, which is not among the largest 20 cities in the UK - there are no costs for housing to be taken into account, and disposable income after housing costs is therefore identical to that before housing costs. This would not be the case in all locations in the UK with the rents calculated here.

Relationship of social assistance to unemployment insurance in the UK Like Sweden, the UK has a system of compulsory unemployment insurance, so that social assistance payments are not an optional alternative to unemployment benefit.

\section{Germany}

Like the UK, Germany has two schemes that fall within the concept of social assistance. The first is arbeitslosengeld II, which can be claimed either when the entitlement period for arbeitslosengeld $I$, benefits payable under obligatory unemployment insurance system, is up, or if the unemployed person in question does not fulfil the criteria for entitlement to arbeitslosengeld I. Recipients of arbeitslosengeld II must be available for work, and actively seeking a job. The other scheme is sozialhilfe, which is provided for people who are unable to work and who have no other income. Both schemes have the same structure and the same level of benefits, so for our purposes they can be treated as one. Neither of the two schemes is limited in the duration of benefit payments, but a check is made every six months on recipients' fulfilment of the conditions for entitlement.

Like the benefits paid under the Swedish riksnorm, the benefit levels in the German arbeitslosengeld II/sozialhilfe are based on a consumption study - in this case, one carried out in 2008. The German and Swedish systems are also similar in structure, in that both have individual rates of payment for each member of the family, so that the total amount of benefits reflects the size and composition of the family. Children and young people have separate amounts of benefit in accordance with their age category, and benefits increase with age. Once again, 'economies of scale' are taken into account, with a couple receiving less than double the amount for a single person or a lone parent. From 2011 onwards, a special grant was provided towards children's school books and other teaching materials and for leisure activities. 
These are included in the calculations below. It is also possible to receive support for other expenses on a one-off basis. All benefits are of the 'topping-up' type.

The annual benefits received by our family types in 2012 are shown in the upper section of Table 4, in euro.

Table 4. Disposable income before and after housing costs for selected family types in Germany, 2012

\begin{tabular}{|c|c|c|c|}
\hline & Single person & $\begin{array}{c}\text { Lone parent, } \\
2 \text { children } \\
\text { (aged } 7-10 \text { ) }\end{array}$ & $\begin{array}{c}\text { Couple, } \\
2 \text { children } \\
\text { (aged } 7-10 \text { ) }\end{array}$ \\
\hline Amount of benefit: & 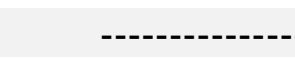 & EURO -..- & - \\
\hline Adults & 4,488 & 4,488 & 8,088 \\
\hline Children & - & 6,024 & 6,024 \\
\hline Schoolchildren & - & 200 & 200 \\
\hline Children's leisure activities & - & 240 & 240 \\
\hline Benefit in total & 4,488 & 10,952 & 14,552 \\
\hline $\begin{array}{l}\text { Reduced by amount of child } \\
\text { benefit }\end{array}$ & 0 & 8,736 & 4,416 \\
\hline $\begin{array}{l}\text { Amount of benefit remain- } \\
\text { ing }\end{array}$ & 4,488 & 2,216 & 10,136 \\
\hline Total benefits per year & 4,488 & 10,952 & 14,552 \\
\hline Rent & 5,422 & 7,125 & 7,125 \\
\hline Total grant towards rent & 5,422 & 7,125 & 7,125 \\
\hline Net rent & 0 & 0 & 0 \\
\hline $\begin{array}{l}\text { Disposable income after } \\
\text { housing costs }\end{array}$ & 4,488 & 10,952 & 14,552 \\
\hline
\end{tabular}

Sources: Bundesministerium für Arbeit und Soziales (2012) (www.bmas.de) and own assumptions regarding levels of rent.

All income, including benefits for children (kindergeld and unterhaltsvorschuss), is offset against benefits, as in Sweden.

Just as in Sweden and the UK, reasonable costs for housing are covered in full in Germany, and as in the other two countries there is a variable ceiling for what is considered a reasonable rent (angemessen mietkosten), set according to where in the country the benefit recipient lives. The ceiling in Munich, for example, is twice as high as that in the Ruhr area. Even if the rent paid is considered unreasonably high (unangemessen) in relation to the ceiling, it is covered in full for up to six months in order to allow the benefit recipient time to find cheaper accommodation. If no cheaper accommodation is found, the rent support is reduced to the level of the ceiling. In Bremen in the year 2013 (which means that the figures are a little too high), the following were the 'basic ceilings' and the ceilings in the most expensive areas of the town for our family types:

Ceilings:

Basic level rent High level rent

\section{1 person}

EUR 4,296 per year EUR 5,155 per year
3 people

EUR 6,204 per year EUR 7,445 per year
4 people

EUR 7,200 per year EUR 8,640 per year 
Here, as previously, we have used amounts for rents that correspond to those in Denmark, in that they are calculated on the assumption that rents account for the same proportion of the German AW's income as Danish rents make up of the Danish AW's income. It is assumed that the rents in Germany fall within the limit of what is considered 'reasonable'. Rents and rent support are given in Table 4 in euro/year. Disposable incomes in 2012 before housing costs for recipients of social assistance are calculated as EUR 4,488 for a single person, EUR 10,952 for a lone parent with two children and EUR 14,522 for a couple with two children. The same amounts represent disposable income after housing costs, since net housing costs after payment of benefit are zero. These assumptions do not hold for the basic rent ceiling in Bremen, but they do apply for families with children living in the more expensive area of town. For single people it would be necessary to have a higher ceiling than that in Bremen, but these are to be found in other parts of Germany. There are also towns in Germany, for example Dresden, where the ceilings for all family types would be below the levels of the calculated rents.

\section{Relationship of social assistance to unemployment insurance in Germany}

Like Sweden and the UK, Germany has a system of compulsory unemployment insurance, so that social assistance payments are not an optional alternative to unemployment benefit.

\section{The Netherlands}

In the Netherlands, the social assistance system, Work and Social Assistance (Wet Werk en Bijstand, WWB), is linked to the legal minimum wage, which is regulated in January and July each year. The benefit rate for couples is 100 percent of the minimum wage, for a lone parent it is 70 percent of the minimum wage and for a single person it is 50 percent. If it is not possible for a lone parent or a single person to share a home with another person and thus achieve economies of scale, then the rates paid are 90 percent and 70 percent of the minimum wage respectively. Both these alternatives are shown in Table 5, where Alternative 1 is set at benefit rates of 70 percent and 50 percent for lone parents and single individuals respectively, and Alternative 2, which represents the most common situation, uses rates of 90 percent and 70 percent. These levels constitute the social minimum income in the Netherlands, and incomes below this level can be topped up to it. The average rates per year applicable in 2012 for recipients aged 21 and over (up to pension age) are shown in euro in the upper section of Table 5.

NB. It is assumed that families with children receive an additional 'Child budget' (Kindegebonden budget) payment, and that neither that payment nor normal child benefit are offset against other benefits. There is no system of advance payment from the public authorities of child support due from the other parent, but child support (maintenance payment) at normal rates is offset against the benefit payments. This does not affect the total amount of benefit paid, however. Other incomes are normally offset against the benefit payments. 
Table 5. Disposable income before and after housing costs for selected family types in the Netherlands, 2012

\begin{tabular}{|c|c|c|c|}
\hline & $\begin{array}{l}\text { Single } \\
\text { person }\end{array}$ & $\begin{array}{l}\text { Lone parent, } \\
2 \text { children } \\
\text { (aged } 6-12 \text { ) }\end{array}$ & $\begin{array}{c}\text { Couple, } \\
2 \text { children } \\
\text { (aged } 6-12 \text { ) }\end{array}$ \\
\hline Benefits per year: & $---\cdot$ & ----- EURO -- & ------ \\
\hline Adult (Alternative 1) & 8,020 & 11,228 & 16,040 \\
\hline Adult (Alternative 2) & 11,228 & 14,436 & 16,040 \\
\hline Child benefit & - & 3,340 & 3,340 \\
\hline Total benefit (Alternative 1) & 8,020 & 14,568 & 19,380 \\
\hline Total benefit (Alternative 2) & 11,228 & 17,776 & 19,380 \\
\hline Rent (Alternative 1) & 3,744 & 4,915 & 7,380 \\
\hline Rent (Alternative 2) & 5,617 & 7,380 & 7,380 \\
\hline $\begin{array}{l}\text { Total grant towards rent } \\
\text { (Alternative 1) }\end{array}$ & 1,200 & 2,227 & 3,540 \\
\hline $\begin{array}{l}\text { Total grant towards rent } \\
\text { (Alternative 2) }\end{array}$ & 2,316 & 3,540 & 3,540 \\
\hline Net rent (Alternative 1) & 2,544 & 2,688 & 3,840 \\
\hline Net rent (Alternative 2) & 3,301 & 3,840 & 3,840 \\
\hline $\begin{array}{l}\text { Disposable income after } \\
\text { housing costs (Alternative 1) }\end{array}$ & 5,476 & 11,880 & 15,540 \\
\hline $\begin{array}{l}\text { Disposable income after } \\
\text { housing costs (Alternative 2) }\end{array}$ & 7,927 & 13,936 & 15,540 \\
\hline
\end{tabular}

Sources: Ministry of Social Affairs and Employment (2012) (www.government.nl), own assumptions concerning rents and own calculations of housing benefit.

In the Netherlands, as in Denmark, housing benefit covers part of the cost of rent, but not the whole of it, unlike the situation in Sweden, the UK and Germany. In the same way as for the other countries, the levels of rent used here for the Netherlands are taken as equivalent to those in Denmark in terms of their relationship to the earnings of an AW. Rents and housing benefit for the Netherlands are also shown in Table 5, together with disposable income after housing costs, i.e. total benefit minus net rent, which is given for both Alternative 1 and Alternative 2. In Alternative 2, which is as already noted the most common, annual disposable income after housing costs for a single person is calculated as EUR 7,927, while it is EUR 13,936 for a lone parent with two children and EUR 15,540 for a couple with two children.

In Alternative 1 rents are assumed to be two-thirds of those in Alternative 2 for a single person and a lone parent, but the same as in Alternative 2 for a couple. These rent levels, together with calculated housing benefit, are used in the calculations of disposable income after housing costs in Alternative 1.

Relationship of social assistance to unemployment insurance in the Netherlands In the Netherlands, as in Sweden, the UK and Germany, unemployment insurance is compulsory. Social assistance is therefore for people who do not satisfy the requirements for receiving unemployment benefit from the outset, or whose rights to benefit payments have been used up. 


\section{Comparisons}

Before we present our empirical comparisons, we point out below some similarities among the countries studied. Two countries, Sweden and Germany, use a 'budget method' as the basis for their systems. This means that each family member (though in Sweden, couples are considered jointly) is allocated his or her specific benefit based on consumption studies and an assessment of minimal acceptable consumption. As a result, normal child benefits can be offset against the total benefit granted, since the total benefit already takes the needs of the children into account. The other three countries, Denmark, the UK and the Netherlands, allocate a single benefit amount for each family type while maintaining payment of separate child benefits. In three of the countries, Sweden, Germany and the UK, housing costs are usually covered in full, while there is only partial coverage of rents in Denmark and the Netherlands, provided in both countries in the form of housing benefit, though with the possible addition of a housing supplement in Denmark. The Netherlands is the only country where social assistance - WWB - is directly linked to the legal minimum wage.

Table 6 compares payments under the social assistance systems in the five countries. The upper section of the table shows disposable incomes after housing costs in the relevant national currencies, as given in the calculations in Tables 1-5 above. The lower section of the table gives these same disposable incomes but recalculated to common Purchasing Power Paritycorrected values, in this case in US Dollars. These figures provide a measure of the levels of funds for spending available to recipients of social assistance in the five countries.

Swedish families receiving social assistance have the lowest levels of purchasing power for all the family types. Lone parents and couples with children in Denmark receive the largest amounts in their two categories, with those in the UK getting the second largest amounts. Single individuals in the Netherlands have the highest level of purchasing power, with those in Denmark having the next highest level. Note that a couple in the Netherlands have a disposable income in euro after deduction of housing costs that is around EUR 1,000 greater than that of a German couple in absolute terms, but that nevertheless the purchasing power of the German couple is actually a little higher than that of the Dutch couple - a clear example of the importance of using Purchasing Power Parity correction. 
Table 6. Disposable income after housing costs for recipients of social assistance, given first in national currencies and then in a PPP-corrected common currency, here the US Dollar. 2012.

\begin{tabular}{lccc}
\hline & Single person & $\begin{array}{c}\text { Lone parent, } \\
\text { 2 school-age } \\
\text { children }\end{array}$ & $\begin{array}{c}\text { Couple, } \\
\text { 2 school-age } \\
\text { children }\end{array}$ \\
$\begin{array}{l}\text { In national currencies: } \\
\text { Sweden, SEK }\end{array}$ & 46,080 & 108,000 & 138,360 \\
United Kingdom, GBP & 3,692 & 12,274 & 14,377 \\
Germany, EUR & 4,488 & 10,952 & 14,552 \\
$\begin{array}{l}\text { The Netherlands } \\
\text { (Alternative 2), EUR }\end{array}$ & 7,927 & 13,936 & 15,540 \\
$\begin{array}{l}\text { Denmark, DKK } \\
\text { In PPP-corrected values, }\end{array}$ & 60,991 & 160,138 & 205,431 \\
$\begin{array}{l}\text { USD: } \\
\text { Sweden }\end{array}$ & & & \\
$\begin{array}{l}\text { United Kingdom } \\
\text { Germany }\end{array}$ & 5,075 & 11,894 & 15,238 \\
$\begin{array}{l}\text { The Netherlands } \\
\text { (Alternative 2) } \\
\text { Denmark }\end{array}$ & 5,390 & 17,918 & 20,988 \\
\hline
\end{tabular}

Note: Alternative 2 is used for the Netherlands, since this is the alternative that is directly comparable with other countries.

Sources: Disposable income after housing expenses presented in Tables 1-5 above and the OECD’s 'individual consumption' PPP-corrected currency rates for 2012 in US Dollars.

Next, we calculate net replacement rates for the various family types. The net replacement rate indicates the proportion of a family's income when the adults are working that they receive when their wages are replaced by social assistance. The net replacement rate is thus a relative measure of a family's situation when receiving social assistance compared with their situation when earning, while the PPP-corrected disposable income is an absolute measure of purchasing power in the event of becoming dependent on social assistance supplemented by other benefits related to children and housing. The figures for net replacement rates are calculated on the basis of disposable income after housing costs when the adults in the various family types are in employment, as shown in Table 7 below, and on the disposable income after housing costs for the various family types when they are receiving social assistance, as shown in Tables 1-5 or the upper section of Table 6. 
Table 7. Disposable income after housing costs for the various family types when the adults are working, per year, in the relevant national currencies. Gross income for couples is taken as being $100 \%$ of the AW wage for one person and $80 \%$ for the other. 2012 .

$$
\text { Single person Lone parent, Couple, }
$$
2 school-age children 2 school-age children

\begin{tabular}{lcrr}
\hline Sweden, SEK & 244,049 & 286,884 & 494,244 \\
United Kingdom, GBP & 22,592 & 22,986 & 45,038 \\
Germany, EUR & 21,503 & 29,213 & 47,216 \\
The Netherlands, EUR & & & \\
Alternative 1 & 27,851 & 32,956 & 54,498 \\
Alternative 2 & 25,975 & 30,491 & 54,498 \\
Denmark, DKK & 198,852 & 253,003 & 406,048 \\
\hline
\end{tabular}

Sources: OECD (2013) and own calculations and assumptions regarding rents.

The calculations of disposable income after housing costs are based on AW incomes for all five countries, the descriptions of the tax systems in Sweden, the UK, Germany and the Netherlands in OECD (2013), and our assumptions regarding rents as previously described. For single persons and lone parents using Alternative 1 in the Netherlands, the rent for housing is taken as being two-thirds of that for Alternative 2. It is assumed that lone parents in Germany receive advance child support, unterhaltsvorschuss, which is payable for a total of six years.

Table 8 shows calculations of the net replacement rates. A high net replacement rate means good protection against loss of income upon becoming unemployed, but also a more modest gain in income from working. This can mean problems with incentives for recipients of social assistance to seek work. It must be stressed that the net replacement rates calculated are dependent on the assumptions we have made. Income when in work is very important in this context. We have assumed that if there is one adult in the family he or she will earn 100 percent of the AW wage for the country in question, and that in couples one person will earn 100 percent of the AW wage and the other 80 percent (see Table 7).

Table 8. Net replacement rates for families receiving social assistance. 2012.

\begin{tabular}{|c|c|c|c|}
\hline & Single person & $\begin{array}{c}\text { Lone parent, } \\
2 \text { school-age children }\end{array}$ & $\begin{array}{c}\text { Couple, } \\
2 \text { school-age children }\end{array}$ \\
\hline & \multicolumn{3}{|c|}{-------------Net replacement rate, percent ----------- } \\
\hline Sweden & 19 & 38 & 28 \\
\hline United Kingdom & 16 & 53 & 32 \\
\hline Germany & 21 & 37 & 31 \\
\hline \multicolumn{4}{|l|}{ The Netherlands } \\
\hline Alternative 1 & 20 & 36 & 29 \\
\hline Alternative 2 & 31 & 46 & 29 \\
\hline Denmark & 31 & 63 & 51 \\
\hline
\end{tabular}

Source: Own calculations based on Tables 1-5 in the sections on individual countries, disposable incomes after housing costs, and Table 7.

Rents are also very significant for the results. It is assumed here that families do not find a new home when their income source changes from wages to social assistance. As mentioned earlier, the Danish rent assumptions used in this study are otherwise consistent with the lev- 
els of rent for various family types in the Danish Finance Ministry's 'Law Model', (Finansministeriet, 2004).

None of the net replacement rates calculated here are especially high, so it hardly seems that there would be any problems of incentives to work under the assumptions outlined above concerning wage income. There are, however, large differences in the net replacement rates, both among countries and among family types.

In the cases of Denmark and Sweden, it is remarkable to see that the Swedish net replacement rates are so far below those for Denmark. In part, this is because the 'budget method' used in Sweden to calculate social assistance produces much lower levels of benefit, especially with normal child benefit being offset against total benefits. Another significant factor is the high level of disposable income after housing costs enjoyed by families in work in Sweden, which is in fact attributable to the low levels of income tax. Gross wages (measured as the OECD's AW wage) are in fact a little lower in Sweden than in Denmark, measured in absolute terms in the national currencies.

In the United Kingdom, the net replacement rate for a single person is almost the same as that in Sweden, and for the same reason - low benefits on social assistance and high disposable income after housing costs for single people in work. For the lone parent in the UK, however, the picture is reversed. Lone parents in the UK keep their CTC, Child Benefit and Housing Benefit in addition to social assistance, whereas the equivalent benefits are offset against total benefits in Sweden. When these additional benefits are included, social assistance for lone parents in the UK is high. However, these same benefits, plus WTC, are tapered against income for working parents in the UK, and for a person earning 100 percent of AW income they will be reduced to zero, except for child benefit. In Sweden there is no tapering of child benefits for lone parents in work. The disposable income after housing costs of a working lone parent in the UK is therefore only slightly higher than that of a working single person without children. In consequence, the net replacement rate for a lone parent is significantly higher in the UK than in Sweden, because social assistance payments (including child benefits and housing benefit) in the UK are high, and disposable income after housing costs is relatively low for lone parents in work. In the UK there is no advance payment of child support, as there is in all the other countries except the Netherlands, where this payment is counted in with other child allowances. For the UK couple, the net replacement rate is a little higher than for the corresponding Swedish couple. All in all, families with children and receiving social assistance benefits in the UK are better placed compared to working families than similar families in Sweden, especially lone parent families, while single persons are a little worse off.

The figures for Germany are remarkably close to those for Sweden when the situation is assessed in terms of net replacement rates. Both countries use the 'budget method' to set social assistance rates.

The comparisons for the Netherlands are based on Alternative 2, which is the most usual and which is directly comparable with the situations in other countries. Net replacement rates for single people are in line with those for single people in Denmark. For lone parents, net replacement rates in the Netherlands lie between those for lone parents in Sweden and Germa- 
ny on the one hand and in the UK on the other. For couples with two children, net replacement rates are similar to those for couples in Sweden, Germany and the UK.

Overall, the picture of social assistance found by comparing equivalent benefits in Denmark, Sweden, the UK, Germany and the Netherlands is rather different to that suggested by the categorisation of three types of welfare state suggested by Esping-Andersen (1990). However, it must be emphasised that the comparisons presented here are of the most basic element of the welfare support net, and that it is not possible to generalise from this to other parts of the social security system.

Denmark and Sweden are both considered as operating a social democrat/Scandinavian welfare model, but in 2012 they offered very different levels of benefit to recipients of social assistance, with net replacement rates being considerably higher in Denmark than in Sweden. Germany - which, with the Netherlands, represents the conservative/continental European welfare system - has a social assistance scheme that closely resembles that of Sweden, both with respect to structure and net replacement rates. The structure of the Dutch system, on the other hand, is reminiscent of that of Denmark, and the level of benefit for single persons without children is similar in the two countries. The level of benefits for families with children is much lower in the Netherlands than in Denmark, however. The country with a benefit level that comes closest to that of Denmark for lone parents, however, is the liberal welfare state of the United Kingdom!

The relatively high net replacement rate in the United Kingdom in this case may seem surprising. The explanation is that the UK actually provides very low levels of benefit in the ordinary social assistance system, but that total benefit payments for lone parents are relatively high due to the inclusion of Child Benefit and fairly generous Housing Benefit that increases as income falls, and that disposable income after housing costs for lone parents is low in comparison with that in Denmark and, indeed, in Sweden. This underlines the importance of taking into account the interactions between various benefits, both for people in work and for the unemployed. If such points were overlooked, it would be easy to arrive at the conclusion that the net replacement rates were low in the UK for this family type.

There are also significant differences with regard to the categories and age groups used in social assistance systems. There is a large jump in the level of Danish payments at the point where young people move from young people's benefits to adult benefits. There is no such differential with regard to age and categorisation in, for example, the Swedish system. Nor does the Swedish system make a distinction between married and cohabiting couples; and in Sweden the benefits are tax-free, so there are no problems with differential treatment of social assistance recipients related to their tax situation. Finally, the Riksnorm functions as a poverty line in Sweden. In other words, there is a direct link between poverty and social policy. 


\section{Conclusion}

This paper compares social assistance in Denmark, Sweden, the United Kingdom, Germany and the Netherlands in a specific year, namely 2012. Two of these countries, Sweden and Germany, use a 'budget method' as the basis for their systems. This means that a level of benefit is calculated for each member of the family depending on the civil status of the adults (single or married/cohabiting) and the age of the children, taking family 'economies of scale' into account. In most cases, housing costs are covered in full. This means that child benefit and housing benefit are offset against the total benefits paid to the family.

The structures of the social assistance systems in the UK and the Netherlands, and particularly that in the Netherlands, more closely resemble that of Denmark. In the United Kingdom, housing costs are covered in full for most people. Only in Denmark are social assistance benefits taxable, and only in Denmark is there a voluntary system of unemployment insurance, so that the social assistance system is in effect an optional alternative to qualifying for unemployment benefit. Overall, there are significant structural differences in the social assistance schemes in the five northern European countries considered.

Regardless of the means of comparison used - PPP-corrected amounts of benefit or net replacement levels in relation to income from wages when in employment - the Danish social assistance benefits are the highest or among the highest in the five countries, while those paid in Sweden are the lowest or among the lowest, but generally very much on a par with those in Germany. Benefits in the UK for families with children are in the middle of the range, while for single persons without children they are among the lowest. In the Netherlands the picture is more mixed; for single persons without children the benefits are among the highest, for single parents they are around the middle, and for couples with children the benefits are comparatively low.

The heterogeneous nature of the social assistance schemes in the five countries, both with regard to the structures of the schemes and the levels of benefits, may appear surprising. This is especially so in light of the frequently-encountered notion that there is a Scandinavian welfare state model (Sweden, Denmark) that is distinctly different from both the Anglo-Saxon model (the United Kingdom) and the central European model (Germany, the Netherlands). However, it should be remembered that the social assistance scheme is just one part of the social security system, and that its characteristics are not necessarily reflected in the other elements that make up the welfare state. 


\section{References}

Bundesministerium für Arbeit und Soziales (2012). Soziale Sicherung im Überblick 2012. (www.bmas.de)

Danmarks Statistik. 2015. Statistikbanken, forbrugerprisindekset.

(www.statistikbanken.dk/statbank5a)

Esping-Andersen, G. 1990. The Three Worlds of Welfare Capitalism. Princeton: Princeton University Press.

Finansministeriet. 2004. Fordeling og incitamenter 2004. København: Finansministeriet.

Göteborgs Stad Stadsledningskontor. 2012. 'Riksnorm samt förändrede boendekostnader för år 2012'.

(http://www5.goteborg.se/prod/Intraservice/Namndhandlingar/SamrumPortal.nsf/DA3FD 966C68C2C99C12579870047559E/\$File/1.3_20120125.pdf?OpenElement)

Hansen, H. and Schultz-Nielsen, M. L. 2015. Kontanthjælpen gennem 25 år-modtagere, regler, incitamenter og levevilkår. København: Gyldendal.

Jappe, E. 2012. Kontanthjælpshåndbogen 2012. København: Frydenlunds Forlag.

Jappe, E. 2013. Kontanthjælpshåndbogen 2013. København: Frydenlunds Forlag.

Ministry of Social Affairs and Employment. 2012. 'State of Affairs of Social Security' (http://www.government.nl/documents/leaflets/2012/08/02/short-survey-of-socialsecurity-in-the-netherlands-1-july-2012)

OECD. 2013. Taxing wages 2011-2012. Paris: OECD.

Socialstyrelsen. 2015. 'Riksnormen för ekonomiskt bistånd 2006-2016'. (https://www.socialstyrelsen.se/Lists/Artikelkatalog/Attachments/19938/2015-10-14.pdf) 